\title{
Mathematical Tasks as a Means of Improving the Ecological Culture of the Future Teachers
}

\author{
Tatiana Gavaza, Svetlana Lebedeva, Natalia Perkova \\ Pskov state University, Physic and Mathematics faculty \\ Address: Russia, Pskov. Lenin Square, 2
}

\begin{abstract}
With the development of civilization, the environment takes an increasing place in our lives. Analysis of the current state of environmental education of students in the University allows to make a conclusion about the need for a comprehensive approach to the problems of formation of ecological culture of future teachers. One of the directions is the integration of mathematics and ecology. Environmental knowledge can be generated when the study of mathematics through the solution of tasks with environmental content. This article presents mathematical tasks with environmental contents of the different sections of mathematics. Jobs can be used in the process of teaching mathematics students of a direction "Pedagogical education".
\end{abstract}

Keywords: ecological culture, environmental education, mathematical tasks with environmental content.

\section{INTRODUCTION}

With the rapid development of technology, the growth of world population, its economic activity is increasingly important for humanity to become environmental problems and their solutions.

Tough conditions of a global ecological crisis lead to the necessity of the formation and development of ecological culture of the population in the course of continuous ecological education.

Ecological culture is a combination of various qualities, such as environmental knowledge humanistic in nature, the assimilation of values, cultural traditions, rules and norms of behavior in the environment are the cultural achievements of the society [13].

Environmental education is a purposefully organized, planned and systematically carried out the acquisition of ecological knowledge, abilities and skills [9].

The main goal of ecological education in Russia is the formation of socially active personality with high environmental culture is able to adapt to the rapidly changing socio-environmental conditions, aware of the consequences of their actions with a sense of responsibility contemporaries to our descendants for their environmental behavior, focused on continuous self-development [9]. In addressing the objectives is a role for higher education, especially teaching.

The modern teacher, which forms the ecological culture of the personality through various educational processes, needs to be very ecological-active person. The objective condition for this is to ensure that future teachers of integrated system of ecological knowledge, including the study of mathematics.

The analysis of the current status of environmental education and training of future teachers in mathematics leads to the conclusion about inadequate capacity assessment of the relationship of such disciplines as "ecology" and "mathematics". Meanwhile, these Sciences are closely intertwined.

Whole branches of mathematics are created for the analysis of natural phenomena and to solve engineering problems. A universal language suitable for the description of processes of different nature and capabilities based on many factors, is the mathematical apparatus. Mathematics creates conditions for the development of skills among students to quantify the state of natural objects and phenomena, both positive and negative consequences of human activities in the natural and social environment.

In the process of learning mathematics by the students of direction of preparation "Pedagogical education" it is possible to find a material that will present an element of environmental education and illustrate the practical importance of the material being studied, contributing to the development of professional qualities of the teacher. In this connection, you need to define the multidisciplinary context of ecology and mathematics based on the analysis of their role and importance in the process of forming modern scientific picture of the world at the pedagogical University, to develop methods and means of formation of ecological culture of future teachers [6]. http://dx.doi.org /10.17770/etr2017vol1.2525 


\section{MATERIALS AND METHODS}

Because of the importance of environmental issues essential principles of the methodology of environmental education should become the principle of its continuity.

The formation of ecological culture at all stages of learning should be a gradual process, in the process of learning different branches of mathematics.

One means of formation of ecological culture of students in the study of mathematics can be tasks with environmental content. Under objective environmental content understand the challenges associated with quantitative assessment of environmental problems - a model of situations occurring in nature and society, the task - prediction of environmental phenomena, the tasks associated with production labor and management [16].

In the study of mathematics can be used to set the next types:

- information (the content of the job gives an idea about the objects and phenomena related to the environment);

- research (purpose of the job - identify mathematical regularities in natural phenomena, processes);

- demo (the content of the job descriptions of monuments, of the laws of structure of natural objects) [16].

Consider the examples of tasks that teachers use the physics and mathematics faculty of the Pskov state University in the study of the disciplines of basic and elective units for students of a direction "Pedagogical education".

\section{Discipline base unit "Fundamentals of mathematical analysis", "Differential equations"}

The analysis of the fundamental concepts of mathematical analysis from the point of view of continuity of the high school and University we have found that most of the concepts, which are formed in school at different levels of rigor in College courses are treated with the same positions, only deepened, and expanded the range of their application.

The object of study of mathematical analysis are functional dependencies. As is known, the function came into mathematics in connection with the study of the phenomena of nature, and, in particular, physical phenomena and processes. Therefore, in the University in the "Function" it is advisable to include tasks with an environmental content, to show the changes in the environment resulting from production and economic activities of people.

Based on the knowledge of the properties and graphs of basic elementary functions can be offered to students using literature to construct the tasks of environmental issues. They can be made on the issue of soil contamination or air, waste disposal, plant ecology, etc.
With the aim of strengthening the environmental aspect in the initial phase, students can be offered the combined job of the following type.

Task 1: I. Pick up the material on the problem of air pollution and answer the following questions:

- what are the main sources of air pollution on the planet?

- which industries are the most dirty?

- what are the main pollutants today, you know?

- what industries are in your area and how they affect the environment?

- what is the "greenhouse effect"?

II. Make a chart that reflects the percentage of industries that pollute the atmosphere. Make conclusions.

III. Construct a text task with environmental content in which the relationship between the concentration of carbon dioxide and drought on the planet is determined by the linear law.

IV. Decide your objective, plot.

Task 2. Set the dependencies between the variables (environmental indicators) and the construct:

- tasks on the problem of air pollution;

- tasks on the problem of water pollution;

- tasks on the problem of purification of used water;

- task of environmental management;

- the task of feeding ecology;

- the task of ecology and energy resources.

With this organization of learning activities, the student plays the role of the researcher, i.e., collects the facts, analyzes, compares, establishes interdisciplinary connections, builds a mathematical model that translates the problem into natural language. [5]

If the function describes the process of change of one quantity depending on another change, the rate of change function describes the derivative. The huge value of the derivative is that the study of all processes and phenomena of nature with its help it is possible to estimate the rate of change of related quantities.

Task 3. The decay of radium according to the law where the quantity of radium in the initial time $t=0$, and $\mathrm{R}$ is the number neraspavshemsya of radium at time $t$. Determine the law of dependence of the rate of decay of radium with time. Show that the decay rate is proportional to the cash amount of radium.

Senior students are offered tasks with environmental content, which can be solved using differential equations. Many of the processes and phenomena occurring in nature, quantitatively described by ordinary differential equations. They can be used to create a mathematical model of the studied physical, chemical or biological process. The solution of these equations allows to predict the properties of the phenomenon under study and to predict the final result. 
Task 4. The rate of multiplication of certain bacteria is proportional to their number at a given moment of time t. The number of bacteria has tripled within 5 hours. To find the dependence of the number of bacteria with time.

The solution of problem 4 shows that under favorable conditions the increase of bacteria over time is exponential. This law is of interest not only from theoretical but also from a practical point of view. He says that creating a useful population for favorable conditions, it is possible to quickly obtain a population with greater numbers. The exponential law of reproduction is subject to the so-called "ecological explosion", when one or the other species, once in favorable conditions, in a short time reaches large numbers. For example, you can point to the disastrous invasion of hordes of insects (locust, silkworm, etc.).

\section{Discipline base unit "Foundations of mathematical processing of information»}

The purpose of discipline: to form at students the system of mathematical knowledge, abilities, skills, competences necessary for work with information. The studied sections of the discipline: statistical methods for collecting experimental data, methods of primary processing of statistical information the main statistical indicators, statistical indicators and relationships indicators. Official statistical information on the state of the environment can be used as:

- examples of the theoretical concepts;

- content design assignments;

- job statistical research on a particular topic.

Consider the theme of "Series. Performance indicators". The necessary theoretical material used in the solution of problems: determination of a number of speakers, types of time series a graphical representation of the series dynamics, the parameters of intensity development, medium intensity development, development trends, and methods of smoothing of time series.

As an example, an interval of a number of speakers at the lecture provides information on waste production and consumption in the processing of wood and manufacture of wood products in Russia from 2010 to 2015 .

Tab. 1
\begin{tabular}{|r|r|r|r|r|r|r|}
\hline $\begin{array}{r}\mathrm{t}, \\
\text { year }\end{array}$ & 2010 & 2011 & 2012 & 2013 & 2014 & 2015 \\
\hline $\begin{array}{c}\mathrm{y}_{\mathrm{i}} \\
\text { million } \\
\text { tonnes }\end{array}$ & 9,6 & 3,9 & 3,7 & 5,3 & 5,0 & 4,5 \\
\hline
\end{tabular}

In the formation of knowledge and skills to carry out statistical processing of information at practical classes is given the following task: create a series of speakers, to determine its type, to graph, to find analytical indicators, average dynamics, smoothing of time series method, moving average, and draw conclusions. For the job are used statistical data on emissions of air pollutants, which are produced by stationary and mobile sources in Russia from 2009 to 2015y.: 2006 y. - 35510 thousand tonnes; 2007 y. 35532 thousand tonnes; 2008 y. - thousand tonnes; 2009 y. - 32754 thousand tonnes; 2010 y. - 32353 thousand tonnes; 2011 y. -32628 thousand tonnes; 2012 y. - 32469 thousand tonnes; 2013 y. - 32063 thousand tonnes; 2014 y. -31228 thousand tonnes.; 2015 y. -31269 thousand tonnes.

This task, which uses real statistical data, is information. When executed, the problem is not only mathematical, but also ecological education of future teachers. The above task can be supplemented by research done by the student independently. Additional task: a) find information about the most common types of substances that pollute the atmosphere, their impact on the environment; b) to find statistical information on emissions of most common air pollutants produced by stationary and mobile sources; C) to carry out statistical processing of information; g) draw up the results into a concise report. This work can be performed by a group of students. The grouping happens in the mind of air pollutants. Self-employment can be organized in the form of an environmental conference. Fulfillment of additional tasks contributes to the formation of professional qualities of a teacher, development of his ability and willingness to ecological and pedagogical activities.

\section{Discipline of choice "Mathematics and the} harmony of the surrounding world"

The goal of the course is to expand students ' ideas about the concepts of symmetry and proportion, as well as building skills to identify the principle of symmetry (and different types) and the Golden proportion in the phenomena of the surrounding reality, in particular, in ancient architecture.

Teaching about symmetry and the Golden ratio has made significant changes in the scientific picture of the world, has formed a new way of scientific thinking. These concepts have a very broad meaning. They are associated with medicine, biology, chemistry, crystallography, physics, mathematics, philosophy. The proportionality of the Golden section and its related Fibonacci series manifest in the human body at all levels of the organization and functioning of all systems, including the geometry of molecules and cells; the proportions of liquids; dynamics of the heart; the brain biorhythms. The principles of symmetry and the Golden ratio is inherent in nature: in the structure of plants, insects, animals, gems, Earth. The same mathematical patterns that permeate all life. The study of these concepts shows that the world is not random and chaotic, but by the same laws. Therefore, these fundamental knowledge expand opportunities in the field of nature protection as such, and, in particular, of its resources. Moreover, in the future, this knowledge may not only be an 
additional factor in the awareness of the importance of conservation, but also to predict its development and influence on it. So, some studies show that in nature there is a balance that obeys the Golden ratio. If there is a violation of this balance, the natural habitat can be lost [17].

The course content integrate knowledge from different subject areas based on the mathematical concepts of symmetry and the Golden ratio.

By the end of the course students are encouraged to submit a project based on real objects - Pskov churches that dot the city. The aim of the project is to realize the uniqueness of the architecture of ancient Pskov, the importance of saving this cultural heritage, the importance of environmental protection of the city.

Today in the city there are about 40 churches, which require your savings. Pskov is very ancient architecture in harmony with nature, as it is based on the laws of nature - dissymmetry and the Golden ratio. This suggests that Pskov masters knew very well the nature and its laws, and very kind to her, in a world largely lost. One of the reasons for the loss of the harmony of architectural structures - the introduction of measurement standards, in particular the meter.

At the same time, the ancient masters were the units that went from the size of the person - fathoms, cubits, spans, etc. As well as the size of the man laid the Golden proportion, the laws passed and the size of the buildings. Therefore, the architectural features of ancient temples is unique, which in turn requires careful conservation.

For successful completion of the project students are offered the following plan.

1. My goals.

Specify the priority goal, towards which you will strive in carrying out the work.

2. A work plan.

Make a real plan that you follow when it is executed.

3. My first impression.

Describe your first impression about selected objects, their mathematical features. Formulate questions (if any) that you would like to get answers.

4. The facts of history.

Try to collect all possible information about the objects. The result of this work you can collect the following material: the name of the object (and its explanation); if this religious building, information about the Saint in whose honour it was erected; erection time, in honor of the event; alterations (dates, pictures, description of the previous species); the modern form, its function; architecture description; photographs of a modern view of the building from different angles, photos of the modern buildings (if any), plan of the building.

5. Photo gallery.
Make a selection of photos (sketches, images) required for your job. You can view photos of the modern look of the building and its parts from different angles, photographs of the building up to modern construction, building layout, etc.

6. Symmetry and proportionality (mathematical work)

Main directions of the analysis:

- analyze the symmetry of the plan, the individual parts and building as a whole (consider the presence of different types of symmetry elements of symmetry), see how accurately observed symmetry in various parts of the building;

- isolate the building geometric shapes, flat and spatial, and explore their symmetry, scroll shape, having the same symmetry;

- if the architectural elements borders and ornaments, will study their symmetry;

- analyze the building to the presence in its composition of classic types of symmetry (as in the whole building and its separate parts);

- what breaks the overall symmetry of the building and how it affects the harmony of the building?

- analyze the building to the presence in its composition of non-conventional types of symmetry, try to find the cause of a broken symmetry. Is it possible to find the angle from which the building (or any part of it) will look symmetrical?

- try to relate the symmetry of the temple with its history, alterations, functionality of its individual parts.

- look at the numerical patterns in the size structure and its parts, particularly the Golden ratio.

7. Analysis of the state of the environment on the rate of destruction of the temple.

Prepare summary information on the environmental impact of the selected object. Try to talk to the temple workers, museums, architects and restorers on the state of the temple and the environmental impact of its destruction. Analyze the statistics of the state of the climate and the number of anomalies and man-made disasters over the past 10 years and previous 10 years, the change in the chemical state of the air and the impact of these changes on the state of the Church.

8. Areas of concern.

Highlight those issues and problems (if any) that have arisen in the course of work.

9. The results of the study and conclusions.

Analyze your research and make the major your own conclusions on the work done.

10. Interesting information.

Include the material (if any) that seem most interesting in the work.

11. Versions of the reports. 
Prepare the message text for 5-7 minutes about the work done.

12. Bibliography.

Include in this category a list of information sources.

13. The introspection work.

Analyze all the work done.

\section{RESULTS AND DISCUSSION}

The experience of teaching mathematical disciplines for students of the Pskov State University in the direction of "Pedagogical Education" training using assignments of different types allows us to draw the following conclusions:

1. Mathematical tasks of informational type can form the following representations in future teachers:

- about environmental problems;

- on the environmental situation in a particular region;

- on the directions of environmental research;

- on the impact of human activities on the environment;

- on the relationship between the state of ecology and the preservation of monuments of the cultural heritage, the environment.

2. With the help of mathematical tasks of the research type, the formation of representations takes place:

- on the connection between ecology and mathematics;

- on the possible causes of environmental problems and their solutions;

- that the world is organized according to single laws, the violation of which can lead to irreparable consequences.

3. Demonstration tasks allow us to visualize not only the mathematical concepts that are being studied, but also how different spheres of human activity influence the ecological situation, what consequences may have in the "ecological crisis".

4. The use of different types of tasks with environmental content contributes to the formation of beliefs about the need to preserve the environment, cultural traditions, the need to comply with rules and norms of behavior in the environment, the wise use of natural resources, which is an integral part of the environmental culture of the future teacher.

\section{CONCLUSION}

At present, modern research scientists and educators focused on the study of various aspects of environmental education and, in particular, of ecological culture of future teachers.

One of the areas of research can be integration of disciplines "mathematics" and "ecology" through inclusion in educational process of mathematics with environmental content.
The article is recommended for teachers of mathematical disciplines at higher education institutions.

\section{REFERENCES}

[1] Федоров А.Е. Симметрия и искажения в русской традиционной архитектуре: Московский Кремль и другие архитектурные комплексы. - М.: Книжный дом «ЛИБРОКОМ», 2013. - 312 c.

[2] Стахов А., Слученкова А., Щербаков И. Код да Винчи и ряды Фибоначчи. - СПб.: Питер, 2006. - 320с.

[3] Божьеволина И. М. Эколого-педагогическая подготовка студентов в условиях классического университета. Диссертация.... канд. пед. наук.- Казань, 2002. - 230 с.

[4] Перькова Н.В. Методика организации самостоятельной деятельности студентов 1 курса педвуза на занятиях по математическому анализу. Диссертация ... канд. пед. наук. - Санкт-Петербург, 2002.-154 с.

[5] Файрушина С. М. Формирование экологической культуры студентов педагогических вузов в процессе изучения естественнонаучных дисциплин. Диссертация ... канд. пед. наук.- Казань, 2007.- 217 с.

[6] Барышникова Г.Б. Моделирование системы экологического образования студентов направления «Педагогика» (Бакалавриат) // Актуальные проблемы гуманитарных и естественных наук. - 2010. - №9. C.277-281.

[7] Гаваза Т.А. Формирование статистической культуры студентов гуманитарно-педагогических направлений вузов как одной из составляющих общекультурной и профессиональной компетенций //Вестник Псковского государственного университета. Серия «Естественные и физико-математические науки». Выпуск 1. - Псков : Псковский государственный университет, 2012.- С. 111 115.

[8] Дараган Н.Д. Становление экологической культуры будущих педагогов как педагогическая проблема // Вестник Таганрогского института имени А.П. Чехова. 2016. - №2. - стр. 86-91.

[9] Захлебный А.Н. Концепция общего экологического образования в повестке дня XXI века.// Научные исследования в образовании.- 2011- №9. - с.3-6

[10] Лебедева С.В. Роль математического учения о симметрии и золотой пропорции в современном образовании (научная статья) //Вестник Псковского государственного университета. Серия «Естественные и физикоматематические науки». Выпуск 4. - Псков : Псковский государственный университет, 2014. - С. 110 - 113.

[11] Перькова Н.В. Некоторые аспекты изучения темы «Дифференциальное исчисление функции одной переменной» в вузе // Вестник Псковского государственного университета. Серия «Естественные и физико-математические науки». Выпуск 2. - Псков: Псковский государственный университет, 2013.- 220 с. C. $185-188$.

[12] Подзорова М.И. Особенности преподавания математики студентам-экологам.//Ученые записки Российского государственного университета.- 2013- №5. - с. 127-131

[13] Чуйкова Л.Ю. Концепции экологического образования, построенные на идее формирования экологической культуры//Гуманитарные исследования. - 2012 - №2.-с. 342-351

[14] Жолдасбеков А.А., Сихимбаева Ж.С., Шынгысбаева Ж.А. Исследования проблем экологического образования студентов // Современные проблемы науки и образования. - 2012. - № 1.; URL: https://www.scienceeducation.ru/ru/article/view?id=5624

[15] Садыкова Э.Ф., Ниязова А.А. Формирование экологических компетенций в процессе подготовки будущих педагогов// Фундаментальные исследования. 2014. - № 11-9. - C. 2066-2069; URL: https://www.fundamentalresearch.ru/ru/article/view?id=35897 
Tatiana Gavaza, et al., / Environment. Technology. Resources, (2017), Volume I, 97-102

[16] Яркова Г.А., Шебанова Л.П. О проблеме формирования практических умений учащихся при обучении математике в условиях реализации новых образовательных стандартов // Современные проблемы науки и образования. - 2013. - №4; URL: www.scienceeducation.ru/110-9497
[17] Голиков А. Эколого-диссимметрический подход в генетике и селекции видов хвойных. - Германия: LAP LAMBERT Academic Publishing, 2014. - 163 c. 